\title{
ARDUINO UNO BASED AUTOMATIC DESIGN TO BUILD WINE DRINKING TOOL USING SOIL MOISTURE SENSOR
}

\author{
Akbar Sujiwa, S.Si., M.Si *, Oktavianus Hadiwikarta \\ Department of Electrical Engineering, \\ Faculty of Engineering, University of PGRI Adi Buana Surabaya \\ *Corresponding Email address: akbarsujiwa@unipasby.ac.id
}

\begin{abstract}
The development in this era is increasing, humans expect a tool or technology that can help human work, because now technology has become a human need. Therefore, a device that can do watering the wine is made automatically. This tool aims to replace manual work to be automatic. The benefits that can be obtained from this tool is that it can facilitate human work in watering grapes. This tool uses a soil moisture sensor which functions as a soil moisture detector and sends commands to Arduino uno to turn on the relay driver so that the pump can flush water according to soil needs automatically. The making of this final project is done by designing, creating and implementing system components including Arduino uno as a controller, relay drivers for turning on and off the water pump, LCD (Liquid Cristal Display) to display soil moisture values. The results of the research prove that the tool made can function properly and can be developed as expected. The tool can water the vine when the soil humidity is below 50\%, and turn off the pump when the soil moisture is above $50 \%$.
\end{abstract}

Key words: Arduino uno, automatic sprinklers, ground humidity sensor.

\section{INTRODUCTION}

Some grape farmers in Indonesia still depend on the season for farming. This causes agricultural production to be unstable at any time. In the dry season the yields increase but the grape farmers have to water the vines manually and it is done every day. Meanwhile, during the rainy season the production of agricultural products decreases and even crops fail due to heavy rains. This is what causes many farmers to suffer losses and ultimately are disappointed with the yields of their crops. During the dry season the farmers have to spend energy and money to water the vines manually so that the plants can thrive and be able to harvest. Therefore, many consumers who are not satisfied with the results of grape farming during the rainy season, some of those who like to eat grapes choose to grow their own grapes. And seen from the daily activities of those who are busy in the office, there is very little time to water the vines. (Wicahyo. H. 2019)

In the current era of globalization we cannot be separated from development and technology, therefore we must be able to master technology and compete with other countries. Currently, the ease and efficiency of time and energy are the main considerations for humans in carrying out activities from time to time. At this time humans are faced with rapid technological developments that make human work easier. Therefore the author tries to create an automatic wine sprinkler system, where in this tool the author uses a soil moisture sensor and Arduino Uno as the main control and control in this tool. Against this background it will be planned

\section{METHOD}

\subsection{System design}

The design of this system is an innovation that is owned by the author for the development of an automatic wine sprinkler based on the Arduino Uno microcontroller using a soil moisture sensor. The goal of this research is to make it easier for us to water the grapes and find out how the soil moisture sensor works, where the sensor will read dry or humid soil conditions, then move the relay to turn on the 
pump if the soil is dry and turn off the pump when the soil is moist.

a. Block Diagram

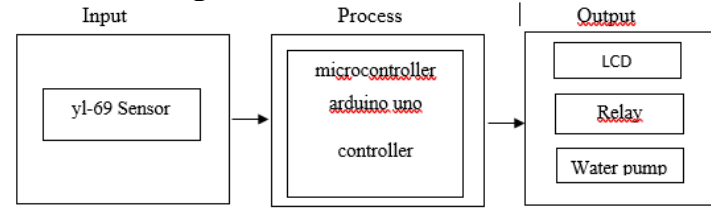

Figure 2.1 Block diagram of the automatic wine sprinkler.

a. Design

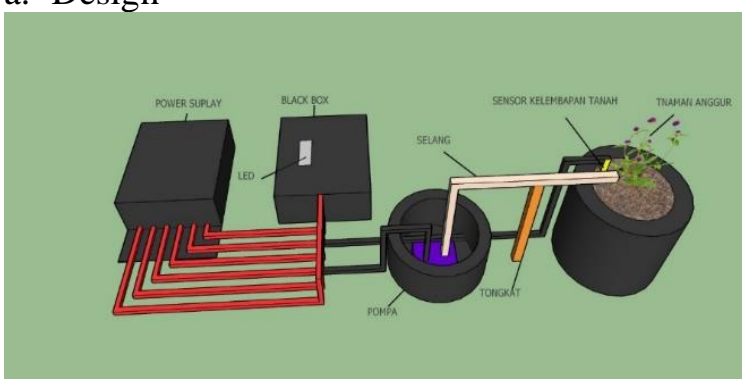

Figure 2.2 Design of automatic wine sprinklers

The black box in the shape of a rectangular box is designed with a length of $18 \mathrm{~cm}$ and a width of $9 \mathrm{~cm}$ to place the components of an automatic plant sprinkler using the Arduino uno, including:
a. Power supply $12 \mathrm{~V}$
b. Soil moisture sensor
c. Arduino uno
d. LCD
e. Relay driver
f. Water pump
g. Grapevine

\subsection{Implementation Place}

In designing and manufacturing this system device, the authors designed and made tools in the Electrical Engineering Laboratory of the University of PGRI Adi Buana, Gedung Sardjijo, Jl. Hamlet dated XII / 4 Surabaya

\subsection{Data Collection Techniques}

In the data collection method this time using the trial observation method, namely the method that is done by:

1. Designing a wine sprinkler for the components used.

2. Test the ability of the soil moisture sensor to read soil conditions
3. Observing the appearance of data received from the soil moisture sensor

4. Perform sensor testing on dry and wet soil

\subsection{Operational Definition of Variables} In this study, there are several variables that aim to get the results achieved.

a. The independent variables are soil moisture sensor.

Variable operational devenition: a tool that can read the amount of moisture in the surrounding soil.

b. The dependent variable is: measurement of soil moisture sensor

Variable operational devenition: The design of this tool is done by reading the soil conditions, and a program on the Arduino uno to process the data.

2.3. Data analysis

Qualitative method, which describes the testing of the tool when it is operated includes:

a) Output output in accordance with demand.

b) Arduino work system

c) Communication between the soil moisture sensor and the Arduino uno microcontroller.

\section{RESULTS AND DISCUSSION}

\subsection{Results}

The results of the system can be seen in Figure 4.1 which is the original image of the device that has been built. Where Arduino uno, relay, LCD, resistor, LED lamp, arranged in such a way in a black box with a size of $\mathrm{P}=18 \mathrm{~cm}, \mathrm{~L}=9 \mathrm{~cm}, \mathrm{~T}=5 \mathrm{~cm}$. Besides the black box there is a $12 \mathrm{v}$ Power Supply, terminal, water tank, pump, soil moisture sensor that is plugged into the vine.

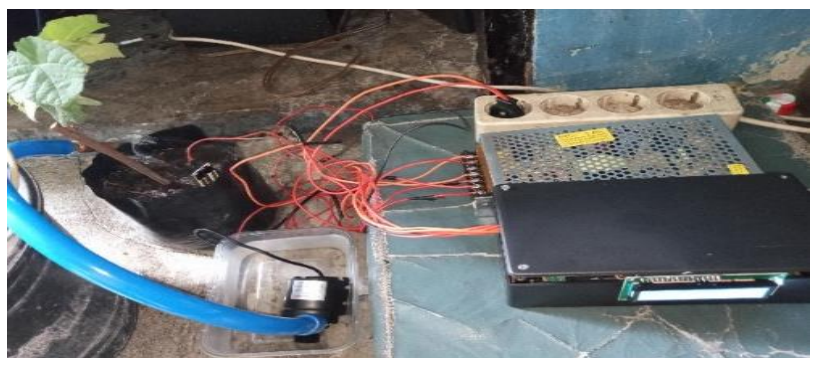

Fig. 3.1 Automatic vine sprinkler based on Arduino uno using soil moisture sensor 
a. The vine sprinkler is on because the soil moisture is at $12 \%$ humidity as shown in the image displayed on the LCD below.

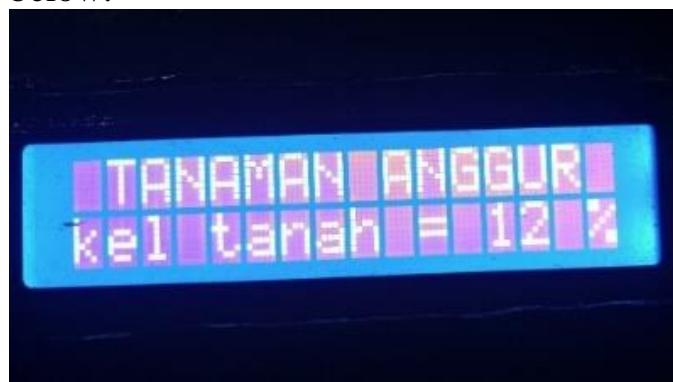

Figure 3.2 Display soil moisture on an

LCD with a humidity of $12 \%$

b. The vine sprinkler is off because the soil moisture is at $89 \%$ humidity as shown in the image displayed on the LCD below.

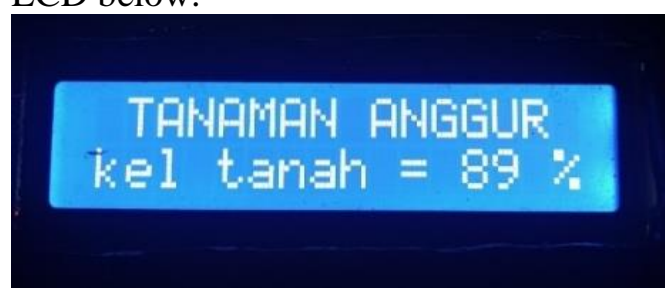

Figure 3.3 Display of soil moisture on an LCD with $89 \%$ humidity

Table 4.1 Measurement results of an automatic vineyard watering device.

\begin{tabular}{|c|c|c|c|}
\hline NO & LCD & $\begin{array}{c}\text { Dry / wet soil } \\
\text { conditions }\end{array}$ & $\begin{array}{c}\text { Pump } \\
\text { ON/OFF }\end{array}$ \\
\hline 1 & $12 \%$ & Dry & ON \\
\hline 2 & $25 \%$ & Dry & ON \\
\hline 3 & $32 \%$ & Dry & ON \\
\hline 4 & $42 \%$ & Dry & ON \\
\hline 5 & $59 \%$ & wet & OFF \\
\hline 6 & $76 \%$ & wet & OFF \\
\hline 7 & $82 \%$ & wet & OFF \\
\hline 8 & $89 \%$ & wet & OFF \\
\hline
\end{tabular}

\subsection{Discussion}

In this discussion, the author will discuss the results of testing the design of an automatic vine watering system using a soil moisture sensor and Arduino Uno. Based on the $\mathrm{RH}$ of the soil that has been set according to the needs of the vine, this tool is also equipped with an LCD (Liquid Crystal Display) which can display soil conditions whether moist or dry according to the reading from the soil moisture sensor in the form of a value on the LCD. This tool is also equipped with a water pump for watering wine, this tool is very useful for us at this time, because with this tool we no longer need to water the vines manually every day, for that this tool can be applied to everyone who likes plant grapes in front of the house or plant grapes in a small garden near the house and in other places that are closed, because this tool is not applied to the open.

\section{CONCLUSION}

Based on the test results, the Arduino Uno based automatic vine sprinkler system can be concluded as follows.

1) The system can water the vines when the soil humidity is below $50 \% \mathrm{RH}$.

2) The system cannot water the vines when soil moisture is above $50 \% \mathrm{RH}$.

3) For the vine the humidity must be brought from $80 \% \mathrm{RH}$ for the vine to flourish.

\section{ACKNOWLEDGMENTS}

The author needs to convey thanks and appreciation to various parties who have provided assistance in the form of guidance, direction, advice, support and convenience from the beginning to the end of the thesis preparation. Do not forget to say thank you to:

1) Both my beloved parents, thank you for your moral and material support

2) Dean of the Faculty of Industrial Technology, Universitas PGRI Adi Buana Surabaya, Mrs. Yunia Dwie Nurcahyanie, ST., MT.

3) Head of Electrical Engineering Study Program Akbar Sujiwa, S.Si., M.Si. 
4) Supervisor Mrs. Atmiasri, ST., MT.,

5) Colleagues Electrical Engineering Study Program friends for their solidarity

\section{BIBLIOGRAPHY}

[1] Anastasya, M.D, Aminudin, A., Tayubi, Y.R., 2019. Sistem Kendali Penyiram Tanaman Menggunakan Propeller Berbasis Internet Of Things

[2] Djuandi, F. 2011. Mikrokontroler arduino uno

[3] Dani. A. W. 2017. Rancang bangun sistem pengairan tanaman menggunakan sensor kelembaban tanah, Vol.8 no.2 151-155

[4] Kafiar, E.Z., Allo, E.K., \& Mamahit, E.J. 2013. Rancang Bangun Penyiram Tanaman Berbasis Arduino Uno Menggunakan Sensor Kelembaban YL39 Dan YL-69, vol.7 no.3, 267-276

[5] Ratnawati, Silma, 2014.Sistem Kendali Penyiram Tanaman Menggunakan Propeller Berbasis Internet Of Things, vol.7 no.2. 147-152

[6] Rochman, Sagita, and Akbar Sujiwa. "Peningkatan Daya Output Generator Listrik Tipe Afpmg Pada Putaran
Rendah Menggunakan 3 Rotor Dan 2 Stator."

[7] Sari, G.M. 2008. Rancang Bangun Alat Penyiram Tanaman Otomatis Menggunakan Sensor Kelembaban Tanah, Politeknik Negeri Medan, 1317

[8] Sujiwa, Akbar, and Sagita Rochman. "Pengembangan Sistem Kontrol Serta Monitoring Suhu dan Volume Air Berbasis Web Pada Perangkat Desalinasi Air Laut." SNHRP (2019): 1-9.

[9] Winoto, A. .2010. Mikrokontroler AVR Atmega 8/32/16/8535 dan Pemrograman pada Win AVR. Bandung Informatika.

[10] Wicahyo, H. 2020. Panduan berkebun organik di pekarangan rumah

[11] Wijaya, H.S., Nugraha, B.S. 2017. Perancangan Alat Penyiram Tanaman Otomatis Dengan Y169 Berbasis Arduino Uno R3, 1-6

[12] Yahwe, P.C., Isnawaty, Aksara, L.M., 2016, Rancang bangun prototype system monitoring kelembaban tanah melalui sms berdasarkan hasil penyiraman tanaman studi kasus tanaman cabai dan tomat, Vol.2, No.1, 97-110 